\title{
Potensi Budidaya Rumput Laut dalam Kaitannya dengan Dampak Perkembangan Pariwisata di Perairan Pantai Kutuh, Badung, Bali
}

\author{
Ayu Putu Wiweka Krisna Dewi ${ }^{\text {a*, }}$ Rani Ekawaty ${ }^{a}$ \\ a Program Studi Manajemen Sumberdaya Perairan, Fakultas Kelautan dan Perikanan, Universitas Udayana, Bukit Jimbaran, Bali-Indonesia \\ * Penulis koresponden. Tel.: +62-81353933396 \\ Alamat e-mail: ayuputu72@gmail.com
}

Diterima (received) 12 Mei 2018; disetujui (accepted) 28 Juli 2018; tersedia secara online (available online) 29 Juli 2018

\begin{abstract}
Seaweed culture is one of the main marine and fishery commodities which mostly still occupied by coastal community in Badung regency. One of the center areas for seaweed culture development is at Kutuh Beach in Kutuh Village South Kuta District, Badung regency . Kutuh Beach also known as Pandawa Beach that have developed become a tourism area. The development of Kutuh beach as tourism area affect the development of existing seaweed culture activities. Therefore, a study have been done to get scientific information related to the development of seaweed culture in Kutuh coastal water. This research was conducted at in September-October 2016. The data was collected by carrying out measurements directly on the location of seaweed culture of Eucheuma cottonii at Kutuh coastal water. The data collected in this study including the growth of seaweed Eucheuma cottonii and the quality of Kutuh coastal waters, such us nitrat, phosphate, temperature, salinity, $\mathrm{pH}$, and dissolved oxygen (DO). Our study showed that that the quality of Kutuh Pantai waters is still in good condition for the growth of seaweed except Phosphor that can inhibit the growth of seaweed. Instead of phosphor, seaweed can not grow well in the waters of Kutuh Beach because it is eaten by predators and low intensity of sunlight.
\end{abstract}

Keywords: seaweed; Eucheuma cotonii; water quality; growth; Kutuh

\begin{abstract}
Abstrak
Budidaya rumput laut merupakan salah satu komoditas unggulan kelautan dan perikanan yang sebagian besar masih ditekuni dan dikembangkan oleh masyarakat pesisir di Pantai Kutuh, Desa Kutuh, Kecamatan Kuta Selatan, Kabupaten Badung. Pantai kutuh yang sekarang dikenal sebagai Pantai Pandawa berkembang menjadi daerah pariwisata yang dapat berpengaruh terhadap perkembangan kegiatan budidaya rumput laut yang sudah ada sebelumnya. Perlu dilakukan kajian terkait pengembangan budidaya rumput laut yang ada di Pantai Kutuh pada kondisi saat ini yang berkembang menjadi daerah pariwisata. Penelitian ini dilaksanakan pada bulan September-Oktober 2016. Pengumpulan data dilakukan dengan cara melaksanakan pengukuran secara langsung pada lokasi budidaya rumput laut Eucheuma cottonii di Pantai Kutuh. Data yang dikumpulkan dalam penelitian ini adalah data pertumbuhan rumput laut Eucheuma cottonii dan kualitas perairan Pantai Kutuh, yaitu nitrat, fosfat, suhu, salinitas, $\mathrm{pH}$, dan oksigen terlarut (DO). Berdasarkan hasil penelitian diketahui bahwa kualitas perairan Pantai Kutuh tergolong masih dalam kondisi baik untuk pertumbuhan rumput laut kecuali kandungan fosfat sehingga rumput laut Eucheuma cottonii tidak dapat tumbuh dengan baik di perairan Pantai Kutuh. Selain itu, rumput laut Eucheuma cottonii tidak dapat tumbuh dengan baik di perairan Pantai Kutuh karena dimakan oleh predator dan rendahnya intensitas cahaya matahari.
\end{abstract}

Kata Kunci: rumput laut; Eucheuma cotonii; kualitas air; Pertumbuhan; Kutuh

\section{Pendahuluan}

Rumput laut merupakan salah satu komoditas utama budidaya perikanan yang bernilai ekonomis tinggi dengan peluang pasar yang luas, baik pasar lokal maupun internasional. Rumput laut dapat dibudidayakan secara masal sehingga menjadi salah satu komoditas strategis dalam program 
revitalisasi perikanan yang dicanangkan Kementerian Kelautan dan Perikanan. Volume produksi perikanan budidaya rumput laut adalah sebesar 1.944 .800 -ton atau $55.07 \%$ dari total produksi budidaya di Indonesia pada Tahun 2010 (KKP, 2011).

Budidaya rumput laut memiliki peranan penting dalam usaha meningkatkan produksi perikanan untuk memenuhi kebutuhan pangan dan gizi, memperluas kesempatan kerja, meningkatkan pendapatan dan kesejahteraan nelayan dan petani ikan serta menjaga kelestarian sumber hayati perairan (Aslan, 1998). Kegiatan budidaya rumput laut merupakan salah satu komoditas unggulan kelautan dan perikanan yang sebagian besar masih ditekuni dan dikembangkan oleh masyarakat pesisir di Pantai Kutuh, Desa Kutuh, Kecamatan Kuta Selatan, Kabupaten Badung.

Desa Kutuh memiliki potensi laut yang cukup luas dalam pengembangan kegiatan perikanan khususnya untuk budidaya rumput laut yang selama ini telah mampu mengangkat perekonomian masyarakat yang ada di Desa Kutuh. Arthana dkk. (2012) menyatakan bahwa wilayah perairan tenggara pulau Bali layak digunakan sebagai lokasi budidaya rumput laut, salah satunya adalah Perairan Pantai Kutuh, Badung. Suwariyati dkk. (2014) menambahkan bahwa jenis rumput laut yang dibudidayakan di Pantai Kutuh adalah Eucheuma cottonii dan Eucheuma spinosum.

Pantai kutuh yang sekarang dikenal sebagai Pantai Pandawa berkembang menjadi daerah pariwisata. Perkembangan itu dapat mempengaruhi perkembangan kegiatan budidaya rumput laut yang sudah ada sebelumnya, namun pembudidaya tetap mempertahankan kegiatan budidaya rumput laut (Suwariyati dkk., 2014; Dewi dan Saraswati, 2016). Perkembangan pantai kutuh menjadi daerah pariwisata tentu dapat berpengaruh terhadap perkembangan usaha budidaya rumput laut yang sudah ada sebelumnya. Menurut Sumariadhi dan Wijayasa (2012) bahwa perkembangan pariwisata pada suatu daerah dapat menyebabkan beberapa masalah lingkungan, salah satunya adalah masalah limbah yang dihasilkan dari kegiatan pariwisata. Tujuan dari penelitian ini adalah untuk mengetahui kualitas air dan pertumbuhan rumput laut Eucheuma cottonii di Pantai Kutuh.

\section{Metode Penelitian}

Penelitian ini dilaksanakan di Pantai Kutuh, Desa Kutuh, Kecamatan Kuta Selatan, Kabupaten
Badung pada bulan September-Oktober 2016. Pengumpulan data dilakukan dengan cara melaksanakan pengukuran secara langsung pada lokasi budidaya rumput laut Eucheuma cottonii. Data yang dikumpulkan adalah data pertumbuhan rumput laut Eucheuma cottonii dan kualitas air budidaya rumput laut Eucheuma cottonii yaitu nitrat, fosfat, suhu, salinitas, $\mathrm{pH}$, dan oksigen terlarut (DO).

\section{Hasil dan Pembahasan}

\subsection{Kualitas Perairan Pantai Kutuh}

Data kualitas perairan Pantai Kutuh dapat dilihat pada Tabel 1.

Tabel 1.

Data Kualitas Perairan Pantai Kutuh

\begin{tabular}{cccc}
\hline No. & Parameter & Satuan & Nilai \\
\hline 1 & Suhu & ${ }^{0} \mathrm{C}$ & $29,07 \pm 0,31$ \\
2 & pH & & $8,11 \pm 0,07$ \\
3 & Salinitas & ppt & $32,83 \pm 0,41$ \\
4 & DO & ppm & $6,7 \pm 0,35$ \\
5 & Posfat & ppm & $0,028 \pm 0,02$ \\
6 & Nitrat & ppm & $0,589 \pm 0,01$ \\
7 & Nitrit & ppm & $0,002 \pm 0,01$ \\
\hline
\end{tabular}

\subsubsection{Suhu}

Suhu merupakan salah satu faktor penting yang dapat mempengaruhi pertumbuhan rumput laut. Suhu air dapat berpengaruh terhadap beberapa fungsi fisiologis rumput laut seperti proses fotosintesis, respirasi, metabolisme, pertumbuhan dan reproduksi (Dawes, 1981). Menurut Kadi dan Atmadja (1988), suhu optimum yang sesuai untuk pertumbuhan rumput laut pada genus Eucheuma berkisar antara $27-30^{\circ} \mathrm{C}$. Suhu yang baik untuk budidaya rumput laut sesuai dengan panduan budidaya rumput laut dari WWF-Indonesia (2014) adalah $26-32^{\circ} \mathrm{C}$. Berdasarkan data suhu pada Tabel 1, diketahui bahwa kisaran suhu di perairan Pantai Kutuh berkisar antara 29,07 $\pm 0,310$ C. Hal tersebut menunjukkan bahwa perairan Pantai Kutuh tergolong dalam kondisi yang baik untuk pertumbuhan rumput laut.

Panas yang diterima permukaan laut dari sinar matahari menyebabkan suhu di permukaan perairan bervariasi berdasarkan waktu. Perubahan suhu ini dapat terjadi secara harian, musiman, 
tahunan atau dalam jangka waktu panjang (Assyakur, 2015). Fluktuasi suhu harian di perairan Pantai Kutuh berkisar antara $0,1-0,9{ }^{\circ} \mathrm{C}$ pada setiap jamnya (Gambar 1). Hal ini menunjukkan bahwa tidak terjadi perubahan suhu yang signifikan pada setiap jamnya dalam satu hari dan dengan kata lain dapat dikatakan bahwa perairan Pantai Kutuh memiliki kondisi yang baik untuk pertumbuhan rumput laut. Fluktuasi suhu harian yang besar dalam suatu perairan akan dapat menyebabkan terjadinya stress pada rumput laut.

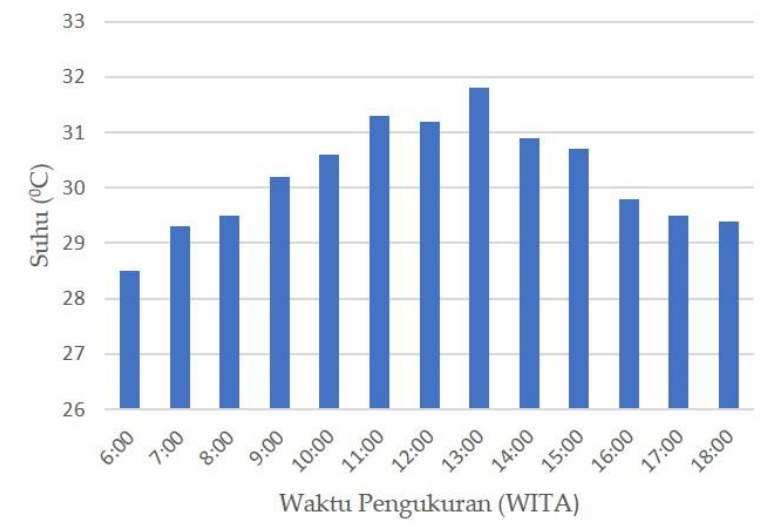

Gambar 1. Fluktuasi Suhu Harian di Perairan Pantai Kutuh

\subsection{2. $\mathrm{pH}$}

$\mathrm{pH}$ perairan berperan dalam pertumbuhan dan perkembangan rumput laut. Menurut Soeseno (1988), nilai $\mathrm{pH}$ yang kurang dari 6,5 akan menekan laju pertumbuhan dan dapat mematikan suatu organisme. Kisaran pH 6,5-9 merupakan kisaran optimal dalam suatu perairan. Menurut WWFIndonesia (2014), $\mathrm{pH}$ perairan yang baik untuk budidaya rumput laut adalah 7-8,5. Kisaran $\mathrm{pH}$ pada perairan Pantai Kutuh selama penelitian adalah 8,01-8,21 (Gambar 2). Hal ini menunjukkan bahwa perairan Pantai Kutuh masih tergolong dalam kondisi yang baik untuk pertumbuhan rumput laut.

\subsubsection{Oksigen Terlarut (DO)}

Oksigen terlarut (DO) merupakan salah satu faktor yang penting dalam kehidupan organisme untuk proses respirasi. Oksigen terlarut dalam air umumnya didapat dari difusi oksigen, arus atau aliran air melalui air hujan dan fotosintesis. Kadar oksigen terlarut bervariasi tergantung pada suhu, salinitas, turbulensi air dan tekanan atmosfer
(Arthana dkk., 2012). Menurut Brotowidjoyo dkk. (1995), oksigen berada pada kondisi alami sehingga jarang dijumpai kondisi perairan terbuka yang miskin oksigen. Berdasarkan data hasil pengamatan diketahui bahwa kandungan oksigen terlarut di perairan Pantai Kutuh berkisar 6,5-7,1 ppm. Hal tersebut menunjukkan bahwa perairan Pantai Kutuh masih tergolong dalam kondisi yang baik untuk pertumbuhan rumput laut. Fluktuasi DO harian dapat dilihat pada Gambar 3.

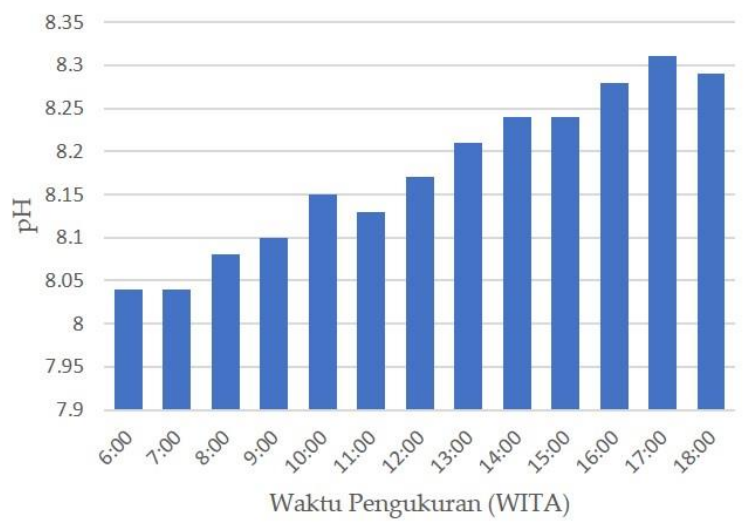

Gambar 2. Fluktuasi pH Harian di Perairan Pantai Kutuh

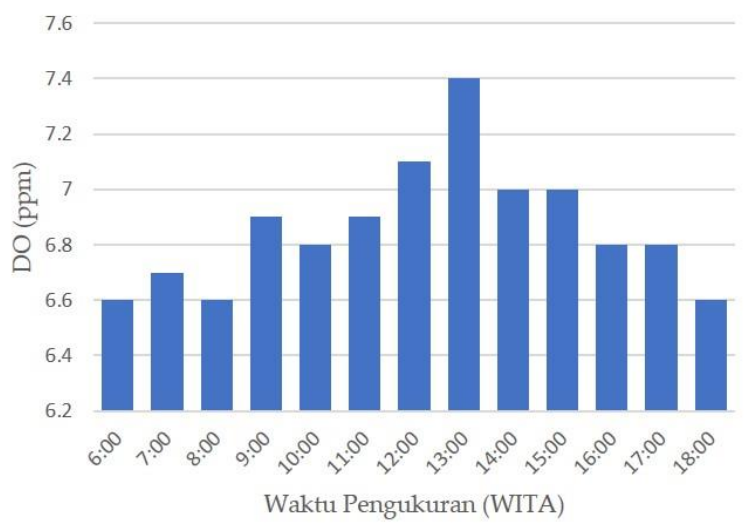

Gambar 3. Fluktuasi DO Harian di Perairan Pantai Kutuh

DO mengalami peningkatan mulai pukul 06.00 sampai dengan pukul 13.00 WITA dan mengalami penurunan mulai pukul 14.00 sampai dengan pukul 18.00 WITA. Kondisi ini berbeda dengan penelitian Hendradjat dkk. (2014) yang menyatakan bahwa oksigen terlarut pada semua perlakuan selama pengamatan mengalami peningkatan mulai pukul 08.00 hingga pukul 17.00, sebaliknya mengalami penurunan setelah pukul 17.00 hingga pagi hari. Hal ini diduga karena kondisi cuaca mulai pukul 11.00 WITA pada saat pengambilan data adalah mendung sehingga 
aktifitas fotosintesis yang terjadi di dalam perairan tidak dapat berjalan dengan baik. Goldman dan Horne (1983) menyatakan bahwa oksigen dalam perairan bersumber dari difusi ataupun hasil proses fotosintesis organisme produsen. Boyd (1990) menyatakan bahwa pada siang hari ketika ada cahaya matahari akan terjadi fotosintesis yang menghasilkan oksigen terlarut dalam jumlah yang banyak sedangkan pada malam hari pada saat tidak ada cahaya matahari, oksigen yang terbentuk selama siang hari akan dipergunakan oleh ikan dan tumbuhan air sehingga sering terjadi penurunan konsentrasi oksigen secara drastis.

\subsubsection{Salinitas}

Salinitas merupakan faktor yang penting bagi pertumbuhan rumput laut. Mekanisme osmoregulasi pada rumput laut dapat terjadi dengan menggunakan asam amino atau jenis karbohidrat. Kisaran salinitas yang rendah dapat menyebabkan pertumbuhan rumput laut menjadi tidak normal. Doty (1973) menyatakan bahwa salinitas yang dikehendaki oleh rumput laut Eucheuma yaitu berkisar antara 29-34 ppt. Sedangkan Kadi dan Atmadja (1988) menyatakan bahwa kisaran salinitas untuk pertumbuhan rumput laut yaitu 30-34 ppt. Pada beberapa jenis rumput laut, salah satunya Gracillaria, memiliki toleransi terhadap kisaran salinitas yang tinggi, akan tetapi pertumbuhan optimal hanya dapat terjadi pada salinitas 30 ppt (Luning, 1990). Selain itu, fungsi reproduksi berupa pelepasan spora Gracilaria sp biasanya berlangsung pada salinitas 10-40 ppt (Yamase and Lirman, 2012). Salinitas perairan Pantai Kutuh selama penelitian adalah 3233 ppt (Gambar 4). Hal tersebut menunjukkan bahwa perairan Pantai Kutuh masih tergolong dalam kondisi yang baik untuk pertumbuhan rumput laut.

\subsubsection{Unsur Hara}

Rumput laut membutuhkan nutrien dalam jumlah yang cukup dan seimbang agar dapat tumbuh dan mencapai produksi yang optimal (Radulovich et al., 2015). Rumput laut memerlukan adanya unsur hara, baik unsur hara makro maupun unsur hara mikro. Unsur hara yang banyak dibutuhkan dalam pertumbuhan rumput laut adalah nitrat dan fosfat. Kandungan nitrat di perairan pantai kutuh adalah $0,589 \pm 0,01$ ppm. Kisaran ini masih dalam kondisi optimal untuk pertumbuhan rumput laut. Hal ini sesuai dengan Flukes et al. (2015) yang menyatakan bahwa kisaran nitrat yang baik untuk pertumbuhan organisme yang dibudidayakan adalah 0,20-0,66 ppm. Menurut Corey et al. (2013), kandungan nitrat yang mampu mendukung kehidupan dan pertumbuhan rumput laut adalah lebih besar dari 0,014 ppm.

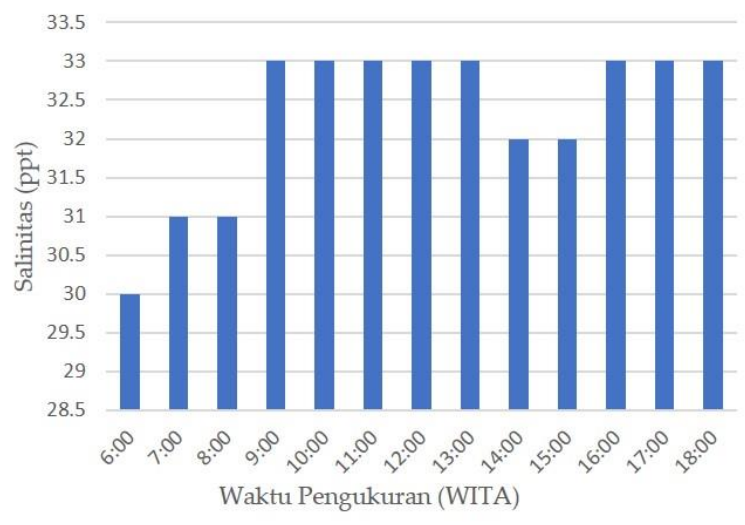

Gambar 4. Fluktuasi Salinitas Harian di Perairan Pantai Kutuh

Kandungan fosfat di perairan Pantai Kutuh adalah 0,028 $\pm 0,01 \mathrm{ppm}$. Kandungan tersebut lebih rendah dibandingkan dengan kisaran fosfat optimal yang dibutuhkan rumput laut untuk dapat tumbuh dengan baik. Yala et al. (2017) menyatakan kisaran fosfat yang optimal untuk pertumbuhan rumput laut adalah 0.05-1.00 ppm. Hal ini yang menyebabkan rumput laut tidak dapat tumbuh dengan baik di Perairan Pantai Kutuh. Radulovich et al. (2015) mengemukakan bahwa jika salah satu unsur hara tidak tersedia, maka dapat menyebabkan pertumbuhan, perkembangan serta produksi rumput laut terhambat.

Rendahnya kandungan fosfat di perairan Pantai Kutuh diduga disebabkan karena tidak adanya masukan unsur hara dari luar perairan Pantai Kutuh. Daerah budidaya rumput laut di perairan Pantai Kutuh berada di Teluk yang terlindung oleh tebing-tebing tinggi dan tidak ada aliran air yang menuju ke perairan Pantai Kutuh. Hal ini sesuai dengan Asni (2015) yang menyatakan bahwa rendahnya kandungan unsur hara di dalam suatu perairan disebabkan oleh tidak adanya aliran air yang menuju ke perairan sehingga tidak ada masukan unsur hara dari luar perairan terutama pada saat musim hujan.

\subsection{Pertumbuhan Rumput Laut Eucheuma cottonii}

Berdasarkan hasil penanaman rumput laut Eucheuma cottonii selama penelitian, diketahui 
bahwa rumput laut tidak dapat tumbuh pada perairan Pantai Kutuh selama penelitian. Hal ini dapat dilihat dari habisnya rumput laut setelah 3 hari ditanam. Habisnya rumput laut selama masa tanam diduga bahwa rumput laut tidak dapat tumbuh karena rumput laut mengalami kekurangan nutrien yaitu fosfat. Selain itu, rumput laut Eucheuma cottonii tidak dapat tumbuh dengan baik di perairan Pantai Kutuh karena dimakan oleh predator. Rendahnya intensitas cahaya matahari selama penelitian juga merupakan faktor penghambat pertumbuhan rumput laut. Cahaya merupakan salah satu faktor penentu perkembangan kehidupan tumbuhan air yang secara langsung ataupun tidak menentukan kehidupan organisme lainnya yang menjadikannya sebagai makanan. Cahaya menyediakan energi bagi terlaksananya fotosintesis (zona eufotik), sehingga kemampuan penetrasi cahaya sampai pada kedalaman tertentu sangat menentukan distribusi vertical organisme perairan (Fourqurean et al., 2012).

\section{Simpulan}

Kualitas perairan Pantai Kutuh tergolong masih dalam kondisi baik untuk pertumbuhan rumput laut kecuali kandungan fosfat sehingga rumput laut Eucheuma cottonii tidak dapat tumbuh dengan optimal di perairan Pantai Kutuh. Selain itu, rumput laut Eucheuma cottonii tidak dapat tumbuh dengan baik di perairan Pantai Kutuh karena dimakan oleh predator dan rendahnya intensitas cahaya matahari.

\section{Ucapan terimakasih}

Atas asung kerta wara nugraha Ida Sang Hyang Widhi Wasa, penelitian ini dapat terlaksana dengan baik. Penelitian ini dapat terlaksana atas dana dari Fakultas Kelautan dan Perikanan, Universitas Udaya. Penulis mengucapkan terimakasih kepada semua pihak yang telah membantu penelitian ini, mulai dari penyusunan proposal, pelaksanaan penelitian sampai penulisan laporan.

\section{Daftar Pustaka}

As-syakur, A. R. (2015). Spatio-Temporal Variations of Rainfall and SST Anomaly over Indonesia during ENSO Modoki Event in 2010. Journal of Marine and Aquatic Sciences, 1(1), 23-29.
Arthana, I. W., Pertami, N. D., Hendrawan, I. G., Wijayanto, D. B., Perwira, I. Y., \& Ulinuha, D. (2012). Pemetaan potensi kawasan budidaya rumput laut di perairan tenggara Pulau Bali. Laporan Penelitian. Bukit Jimbaran, Indonesia: Fakultas Kelautan dan Perikanan Universitas Udayana.

Aslan, L. M. (1998). Budidaya Rumput Laut. Yogyakarta, Indonesia: Kanisius.

Asni, A. (2015). Analisis produksi rumput laut (kappaphycus alvarezii) berdasarkan musim dan jarak lokasi budidaya di perairan kabupaten bantaeng. Jurnal Akuatika. 6(2), 140-153.

Boyd, C.E. (1990). Water quality in ponds for aquaculture.. Alabama, USA: Departement of Fisheries and Allied Aquacultures Auburn University.

Brotowidjoyo, M. D, Tribawono, D., \& Mulbyantoro, E. (1995). Pengantar Lingkungan Perairan dan Budi Daya Air. Yogyakarta, Indonesia: Liberty.

Dawes, C. J. (1981). Marine Botany. New York, USA: John Wiley \& Sons.

Dewi, A. P. W. K., \& Saraswati, S. A. (2016). Kajian Pengembangan Usaha Budidaya Rumput Laut Di Pantai Kutuh, Badung, Provinsi Bali. Journal of Marine and Aquatic Sciences, 2(1), 1-5.

Doty, M. S. (1973). Eucheuma farming for Carrageenans (Sea grant advisory report). Honolulu, Hawaii, USA: University of Hawaii Sea Grant College Program.

Flukes, E. B., Wright, J. T., \& Johnson, C. R. (2015). Phenotypic plasticity and biogeographic variation in physiology of habitat - forming seaweed: response to temperature and nitrate. Journal of phycology, 51(5), 896-909.

Fourqurean, J. W., Duarte, C. M., Kennedy, H., Marbà, N., Holmer, M., Mateo, M. A., Apostolaki, E. T., Kendrick, G. A., Krause-Jensen, D., McGlathery, K. J., \& Serrano, O. (2012). Seagrass ecosystems as a globally significant carbon stock. Nature geoscience, 5(7), 505-509.

Goldman, C.R. dan A.J. Horne. (1983). Limnology. New York, USA: Mc. Graw Hill.

Hendradjat, E. A., Suharyanto, S., \& Mangampa, M. (2014). Fluktuasi Oksigen Terlarut Harian Pada Tambak Polikultur Udang Windu (Penaeus monodon), Rumput Laut (Gracilaria sp.), dan Ikan Bandeng (Chanos chanos). Dalam Prosiding Forum Inovasi Teknologi Akuakultur 2014. Maros, Indonesia, 6-8 Mei 2014 (pp. 295-302).

Kadi, A., \& Atmadja, W. S. (1988). Rumput laut (Algae): jenis, reproduksi, produksi, budidaya, dan pasca-panen. Jakarta, Indonesia: Pusat Penelitian dan Pengembangan Oseanologi, Lembaga Ilmu Pengetahuan Indonesia (LIPI)

KKP. (2011). Kelautan dan Perikanan dalam Angka 2011. Jakarta, Indonesia: Kementerian Kelautan dan Perikanan Republik Indonesia. 
Largo, D. B., Fukami, K., \& Nishijima, T. (1995). Occasional pathogenic bacteria promoting ice-ice disease in the carrageenan-producing red algae Kappaphycus alvarezii and Eucheuma denticulatum (Solieriaceae, Gigartinales, Rhodophyta). Journal of applied phycology, 7(6), 545-554.

Lüning, K. (1990). Seaweeds: Their Environment, Biogeography and Ecophysiology. New York, USA: John Wiley \& Sons.

Radulovich, R., Umanzor, S., Cabrera, R., \& Mata, R. (2015). Tropical seaweeds for human food, their cultivation and its effect on biodiversity enrichment. Aquaculture, 436, 40-46.

Soeseno, S. (1988). Budidaya ikan dan udang dalam tambak. Jakarta, Indonesia: PT. Gramedia.

Sumariadhi, N. W., \& Wijayasa, I. W. (2012). Dampak Pariwisata di Nusa Lembongan. Jurnal Perhotelan dan Pariwisata, 2(2), 23-47.
Suwariyati, N. W. E., Susrusa, I. K. B., \& Rantau, I. K. (2014). Perbedaan Pendapatan Usahatani Rumput Laut Eucheuma spinosum dan Eucheuma cottonii di Desa Kutuh Kecamatan Kuta Selatan. E-Jurnal Agribisnis dan Agrowisata, 3(1), 22-31.

Winarno. (1996). Teknik Pengolahan Rumput Laut. Jakarta, Indonesia: Pustaka Sinar Harapan.

WWF-Indonesia. (2014). Seri Panduan Perikanan Skala Kecil: Budidaya Rumput Laut - Kotoni (Kappaphycus alvarezii), Sacol (Kappaphycus striatum) dan Spinosum (Eucheuma denticulatum). Jakarta, Indonesia: World Wildlife Fund (WWF) - Indonesia.

Yamase, N., \& Lirman, D. (2012). Growth And Competition Of Anadyomene In Biscayne Bay, Florida. In Society for Advancement of Chicanos/Hispanics and Native Americans in Science National Conference 2012. Seattle, WA, 12 October 2012.

(C) 2018 by the authors; licensee Udayana University, Indonesia. This article is an open access article distributed under the terms and conditions of the Creative Commons Attribution license (http://creativecommons.org/licenses/by/3.0/). 